\title{
Blended learning and bilingual education
}

\author{
Elena Firpo ${ }^{\text {a }}$ \\ ${ }^{a}$ University of Genoa, Italy, elena.firpo@unige.it
}

\begin{abstract}
The purpose of the applied research presented herein is to devise and promote language teaching paradigms that are intended to develop bilingual abilities in second-generation Latin Americans (aged 11-12 years) in the Italian middle school, thereby recovering their original linguistic background, while amplifying their knowledge of Italian, thus redefining a carefully balanced, pluralistic linguistic framework. Moreover, the study aims to establish a bilingual teaching model that may also be applied to different language pairings.

The LI.LO (acronym for Italian Language/Native Language) programme was designed and delivered in blended learning on Sybra/CLiRe (Centro Linguistico in Rete) platform of the University of Genoa and it focuses on the development of bilingual skills with respect to academic language, cognitive abilities, and computer competence. It promotes language proficiency and the complete integration of non-Italian, second-generation Latin American students.

The first part of the study illustrates Italian linguistic policies, underscoring the need to close the gap between the actual state of the Italian school system and extant norms. The second part of the study shows the theoretical and methodological assumptions of the blended model of the course LI.LO as well as the course activities. The third part of the article shows the results of the evaluation and self-evaluation questionnaires administered after the study's completion.
\end{abstract}

Keywords: Blended learning, bilingualism, CALP, study skills.

\section{Introduction}

The Italian education system is based on the principles laid down in Articles 3, 33 and 34 of the Constitution of the Italian Republic (Giscel 2007). In particular, Article 34 establishes that 'Schools are open to everyone. Primary education, given for at least eight years, is compulsory and free[...] ${ }^{1}{ }^{1}$ Compulsory education is currently provided up to the age of 16 years.

The Italian school system, based essentially on the provision of education by the State, is experiencing significant changes determined principally by the global economic crisis and the increase in the number of pupils coming from outside Italy, such as from other European Union (EU) Member States, but -above all -from countries outside the EU.

According to statistics published by Italy's Ministry of Education, Universities and Research in 2015, the number of non-Italian students equaled 805,800 ( $9.2 \%$ of the total). The same year saw an overall increase in the number of foreign students due -above all -to non-Italian students born in Italy, who make up more than half (51.7\%) of the total number of foreign students (Fig.1). While in previous years, the increase in the number of foreign students in Italian schools resulted from immigration, more recently, this increase is due to a rise in the number of foreign students born in Italy. Italian citizenship is essentially awarded by having one or both parents as Italian citizens, i.e. the principle of ius sanguinis. $^{2}$

\footnotetext{
${ }^{1}$ Constitution of the Italian Republic, available at www.senato.it/documenti/repository/istituzione/costituzione_inglese.pdf

${ }^{2}$ The principle of ius sanguinis (Latin: right of blood) differs from ius soli, where citizenship is determined by the place of birth, irrespective of parents' nationality.
} 


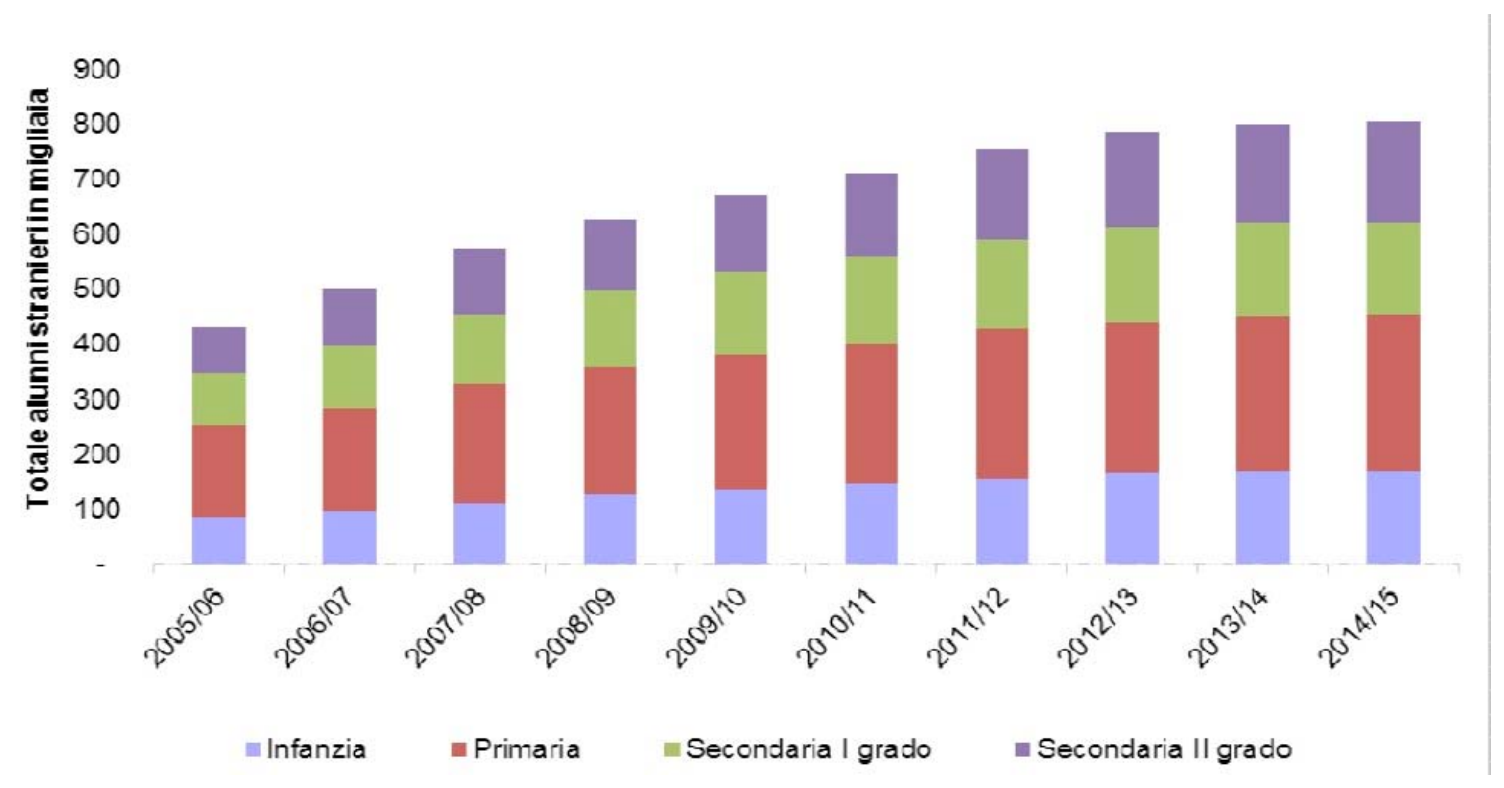

Fig 1. Foreign students attending Italian schools -school year 2014/2015 (Ministry for Instruction, University and Research, Ufficio Statistico, Ottobre 2015, p. 5).

Figures regarding the performance of foreign students and their choice of high school are not encouraging: foreign students obtain lower results than Italian children and few carry on into the second phase of secondary education from the age of 13/14 years onwards (Fig. 2).

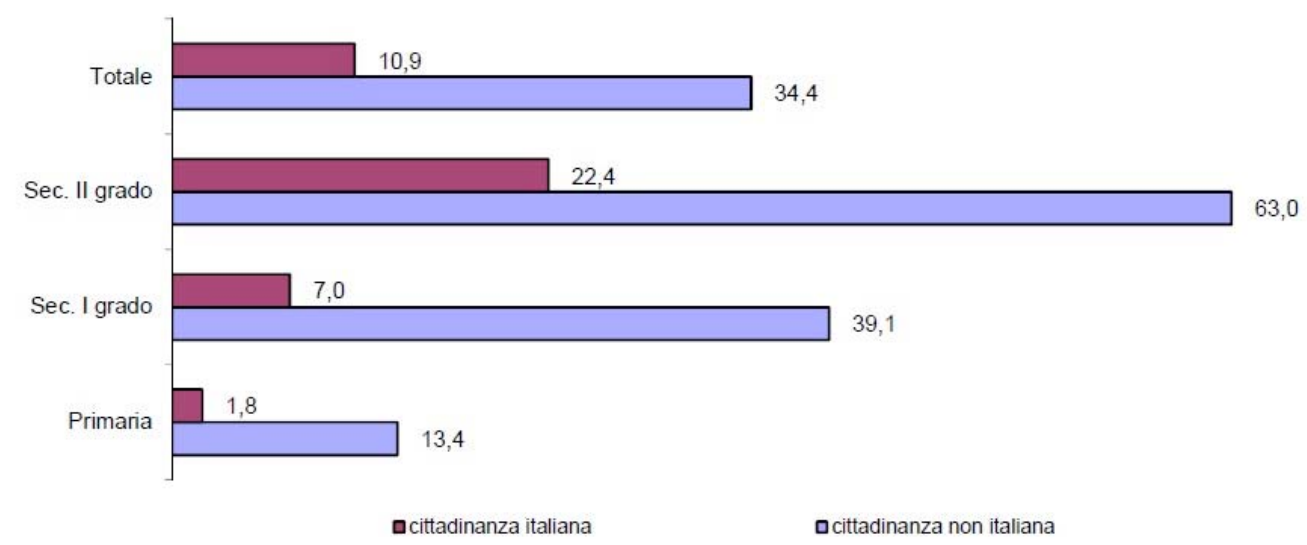

Fig. 2. Backwardness of foreign students at school -school year 2014/2015. (Ministry for Instruction, University and Research, Ufficio Statistico, Ottobre 2015, p. 19).

Figure 3 shows that, after middle school, foreign students choose mostly technical and professional secondary schools.

These data are intended to provide the reader with an overview of some important aspects of the situation in the Italian school system in the context of foreign students, such as the amount and quality of fractional generations in the classes, the performance of students and the choice of the secondary school.

The conditions of current schools, together with the observations of the writer, have raised the questions for this research and all the ways connected to them. The first question concerns whether a second-generation foreign pupil who has achieved cognitive academic language proficiency (CALP) is equal to an Italian one. The answer to the first question, considering these data, combined with linguistic screening tests performed during this research (Firpo, 2014), have led to the hypothesis that the CALP of Italian pupils is higher than that of foreign students.

The second question, related to the the first one, concerns the method of study. It demands research into whether working with two languages using information and communications technology (ICT) could be a valuable aid for second-generation students to implement language and study skills.

The results of the language tests carried out before and after the two editions of the courses have led to the hypothesis that students who attend the courses have improved performance (Firpo \& Sanfelici 2015). 


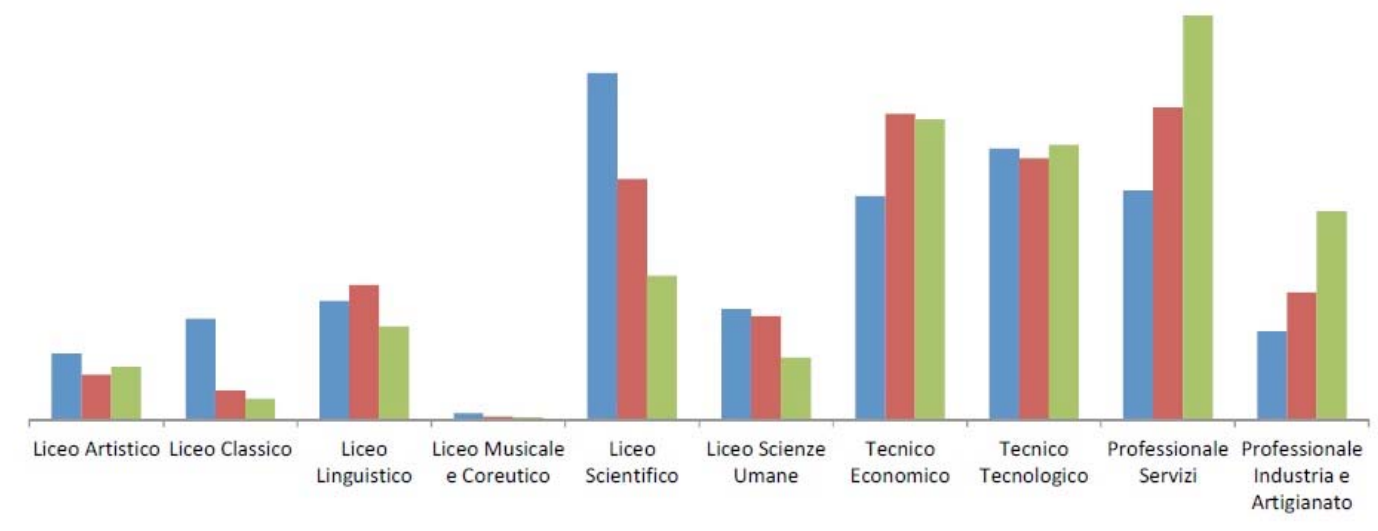

Italiani $\quad$ Stranieri nati in Italia Stranieri nati all'estero

Figure 3. Distribution of secondary school students by type of school -school year 2014/2015 (Ministry for Instruction, University and Research, Ufficio Statistico, Ottobre 2015, p.11).

\section{Definitions and key concepts}

Before proceeding to discuss the issue, it is considered appropriate to define certain concepts relating to this study, such as academic language and fractional generation, the latter being a term used to identify the different age groups in which an individual, a son/daughter of immigrants, has become part of a society. The first definition taken into account is that of fractional generation.

According to Rumbaut's (1997, p. 29) definition, 'By generation, 44\% of immigrants are Us-born children of immigrant parents (i.e. the second generation or 2.0 generation), and $56 \%$ are foreign-born youths who immigrated to the United States before age 12 (i.e. the 1.5. generation)'.

For the European Parliament, knowledge of the host country's language is highlighted as a fundamental prerequisite for integration into the mainstream education system. A majority of publications emphasize the need for powerful and early intervention for the acquisition of the teaching language, which should be followed by continuous support during the entire compulsory education phase. ${ }^{3}$

Yet, all of the measures prescribed by the EU were not actually implemented in the Italian classroom. It is not until 2012 that a ministerial directive referred to Special Educational Needs (SENs). The Ministry specified that educational disadvantage does not just explicitly pertain to those affected by some form of disability but covers a far wider spectrum. In all classrooms, certain students may be in need of special attention for a variety of reasons: social and cultural disadvantages, specific learning and/or developmental disorders, as well as the difficulties international students may encounter due to their lack of knowledge of the Italian language and culture. SEN encompasses three subcategories: disabilities; specific developmental disorders; socio-economic, linguistic, and cultural disadvantages.

Because linguistic disadvantages seem to remain an issue, we are still far from adopting practical measures in favour of multilingualism, despite boastful claims to the contrary. Nevertheless, the low performance of foreign students (Fig. 3) ought to lead teachers and politicians to reflect on the need for implementing a way of teaching based on individual needs of the students, with particular attention to the academic language and the study skills. The bilingual education taken into account in this article refers to minority languages spoken by 2.0-generation students of the Italian Middle School. This seems to be a new approach in the Italian School system towards bilingual programmes that are considered, by now, mostly as élite programmes, e.g. the International Schools (García, 2009) or the Content and Language Integrated Learning (CLIL) courses (Euridyce 2006). For the project of this study, we prefer not to consider the term CLIL suitable because bilingual education is not concerned only with the integration of language and content, as implied by the term CLIL, nor is it concerned only with learning another (or more) subject(s) through the medium of a foreign language. Bilingual education is primarily concerned with a student's entire education through two or more languages, including the gradual development of their sense of identity, society and culture.

The second definition taken into account in this paragraph is that of academic language. Dudley-Evans and St John (1998, p. 34) define English for Academic Purposes (EAP) as 'Any English teaching that relates to a study purpose'.

Peacock and Flowerdew (2001, p. 8), however, state that it is 'The teaching of English with the specific aim of helping learners to study, conduct research or teach in that language'.

${ }^{3}$ goo.gl/RLtVlk

REM - Research on Education and Media. Vol. 8, N. 1, Year 2016 - ISSN: 2037-0830 


\section{Blended learning and bilingual education \\ Firpo}

Other authors (Robinson, 1980, 1991; Beard \& Hartley, 1984) linked the concept of EAP to that of study skills, another key word related to the context of the EAP, although in recent years, an acculturation model prevails (Lea \& Street, 2000), in which 'The study skills approach has assumed that literacy is a set of atomised skills which students have to learn and which are then transferable to other contexts' (Lea \& Street, 1998, p. 158).

Relating to the EAP, going back a few years, at the end of the seventies, Cummins (1979b) had introduced the concept of CALP. In an essay in 2002, he observed that immigrant children need different periods of time to become fluent in the second language at the level of conversation (BICS, Basic Interpersonal Communicative Skills) and with respect to the level of educational proficiency (CALP, Cognitive Academic Language Proficiency). Conversational competence is often gained at a functional level within 2 years from the time of the first exposure to a second language, while, usually, at least seven years are needed to reach the level of the native speakers with regard to the educational aspects of the second language (Cummins, 2002).

Fig. 4. Cummins' iceberg.

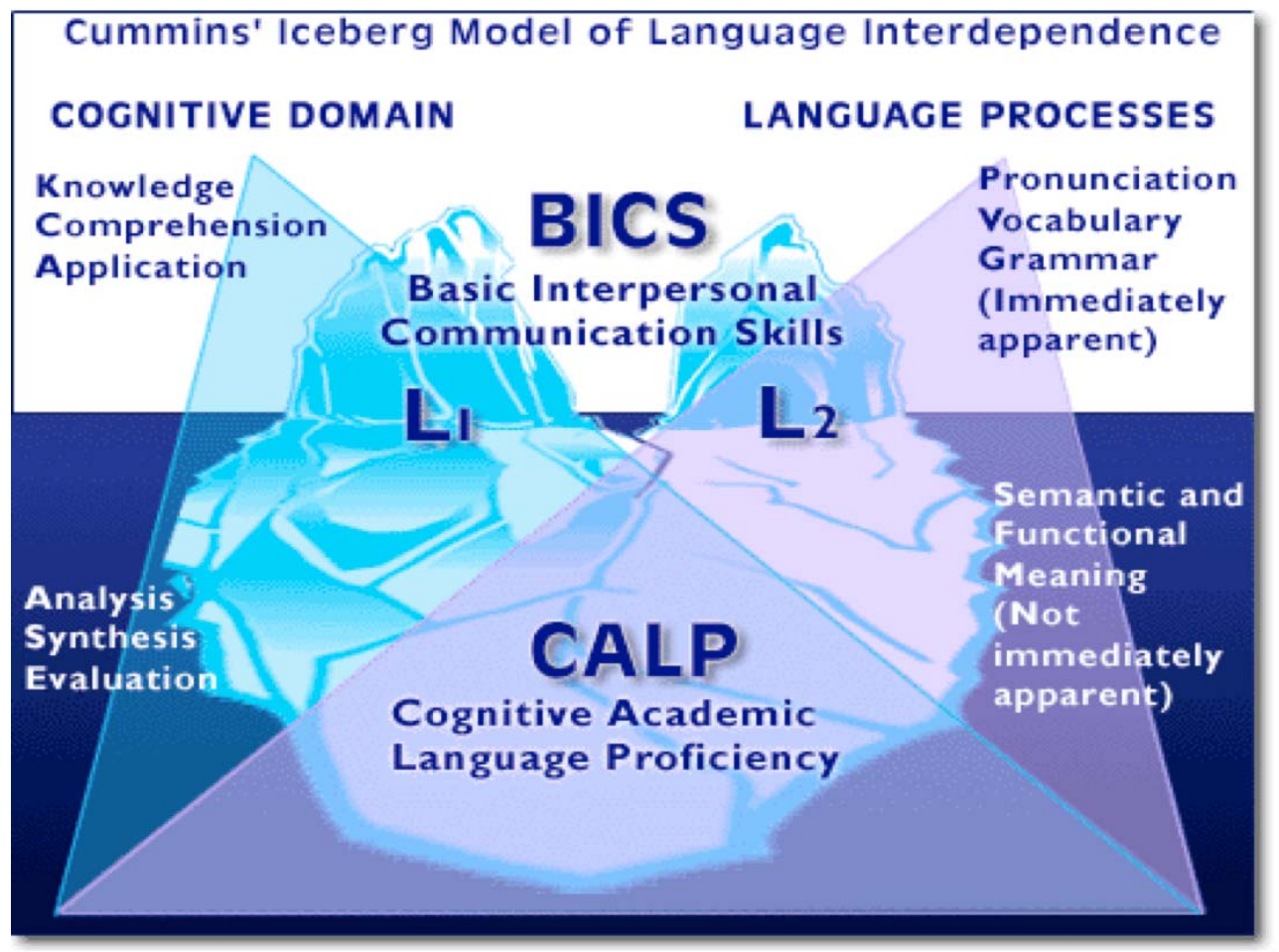

Cummins represents the theory of CALP and BICS by imagining an iceberg that has two emerging points (Fig. 4): they represent the conversational proficiency in both languages, while the academic proficiency of the language, the one that allows to study and achieve high performance, is the base of the iceberg, which is the submerged part. This part includes most of the cognitive and linguistic domain. For this reason, it becomes essential for teachers to be ready and prepared to work with bilingual students.

While the schools of English-speaking countries host foreign students and have been dealing with bilingual education since a long time, in Italy, as previously seen, only in the past 2 decades has the phenomenon of increasing school populations with non-Italian citizens become a fact. Currently, in Italy, the question of the study language in the Italian school system has become a phenomenon of great importance.

Thus, LI.LO (Italian Language/Heritage Language) programme is a research endeavour that intends to develop bilingual skills with respect to academic language, cognitive abilities and intercultural competence. It promotes language proficiency and the complete integration of non-Italian, second-generation students.

In the following sections, the study will analyze the part related to the activities of the course, the use of the Sybra platform and the ICT, and some results of the research. For further information about the linguistic part, refer the cited references (Firpo, 2014; Firpo and Sanfelici 2015).

\section{Literature review}

\subsection{Approaches in language teaching}


In the past 2 decades, language teaching has seen the implementation of computer-assisted language learning (CALL) and consequently, of network-based language teaching (NBLT). These areas, still relatively new and unexplored, but in continuous evolution, find their epistemological foundations in the theories and approaches arising within the discipline.

Although the investigation into CALL is still open and there are no clear boundaries in the areas discussed later, in this paragraph, we intend to provide an overview of the three main approaches of CALL: cognitive, sociocultural and structural. Nowadays, only the first two are paradigms on which research is still under debate (Warschauer and Kern, 2000; Gruba, 2004).

Overall, the distinction between the two approaches, cognitive and sociocultural, is clear: the first focuses on the learner, phenomena and cognitive processes through which learning takes place, while the second focuses on social dynamics (seen as the engine) and the place of language learning. In fact, as previously mentioned, one approach does not exclude the other. Therefore, language teaching in the network can be an interesting research activity because it can combine the scientific strength of cognitive orientation with the effectiveness of sociocultural orientation teaching. Thus, many examples of language teaching in the past 2 decades (i.e. Second Language Learning -SLL, Foreign Language Learning-FLL, CLIL, Bilingual Education-BE) have combined different approaches with the methodological aspects within the CALL, such as the use of ICT and Web 2.0 tools. As regards the LI.LO programme, addressed to foreign students of generation 2.0, we can say that the type of research activity planned and developed for this type of bilingual education course belongs to a still little-explored field. This is due to the novelty of training needs of the Italian School. Consequently, there is no evidence of specific literature about platforms or projects such as the LI.LO, which has been built using new technology and created with the specific aim of developing CALP, increasing study skills and improving the use of technology. Nevertheless, it is conceivable that there are 'good practices' of teachers who use ICT as a result of vocational training. Despite this, it is useful to explore and review literature that explains how and why, today, applied linguistics is going increasingly in the direction of the CALL.

\subsection{The cognitive approach: the constructivism}

At the base of cognitive (or cognitive/constructivist) theory, there is Mason's affirmation, which states that 'The human mind is a complex system of information processing [...] Each new data is incorporated and integrated into existing structures which are enriched, modified, even radically restructured by the new information' (Mason, 2006, p.32).

The theory emphasizes the dynamic character of the acquisition of knowledge that proceeds to enrichment and restructuring, underlining the active role of the learner who processes and transforms the information.

Constructivism is considered an approach in which perspectives on perception, memory, language, learning and therefore-teaching converge. These perspectives consider that the products of these processes should be regarded as the final outcome not only in terms of the action after external stimulations, but especially due to the intense constructive development of the mind.

In the community of authors who identify with the constructivist perspective, there is agreement about the acquisition of knowledge, seen as a process of construction and transformation. The learner does not accumulate new information but processes them by using the knowledge he/she already has. The learner also uses his/her metacognitive skills to establish the learning objectives. In addition, the learning situations should, preferably, be similar to those of real life. The more similar the situation, the greater is the possibility of good transfer of knowledge.

\subsection{The sociocultural approach}

Another point of agreement concerns negotiation and social interaction. They are both important factors in the process of acquiring knowledge because they enable learners to constructively compare their knowledge with that of others.

The models developed from this belief are, first, the community of learners. Bonaiuti states that "The community of learners focuses on practices and shared knowledge... Learning is identified with the process of belonging to the community; after extensive opportunities to practice joint activities, the pupils gradually begin to behave and think as experts: they move from a peripheral participation into a more central (legitimate peripheral participation). Learning is not only an individual value, but assumes the character of a gradual 'affiliation'." (Bonaiuti et al., 2007, p. 49).

The assumption that underlies a community of practice is its right to propose objectives and methodologies adopted in the same way as it does a scientific community, which actively produces knowledge and refines learning strategies and scientific investigation. The practice community is animated by collaboration and cooperation (Ligorio, 1995).

\subsection{The structural approach}


The third approach is that of learning environments supported by the computer as part of language teaching. Historically, one of the first examples of CALL in the sixties, as a branch of the computer-assisted instruction (CAI), was the project PLATO (Suppes and Maken, 1978). This project could administer drill and automatic feedback and it allowed a certain margin of authoring component for the instructors (Gruba, 2004). As the term 'drill' suggests, the dominant approach was the structural one and the various systems that arose in those years referred to this model, in terms of both linguistics and learning, in terms of both design and development. In that context, the role of the computer was that of a tutor, a system where the task was to distribute materials to learners (Warschauer, 1996) and where the working-and-learning process was determined by the structure of the programme itself. Materials were structured according to the well-known path of drill and practice: the stimulus was followed by a response that, consequently, was followed by a confirmation or correction (Richards and Rodgers, 2001). Due to the development of new technologies and the implementation of ICT, nowadays, CALL can provide more flexible models, addressed towards the needs of learners, as well as the learning and teaching environment.

The process of learning and cognitive development is at the basis of modern educational theories, especially those concerning the area of development of study skills and academic language.

The movement of the constructivist perspective towards educational contexts is today supported by new technologies that allow independent access, even if with the help of an adult mediator, as well as knowledge and, above all, the personalization of learning.

At the end of this paragraph, it seems appropriate to quote Papert saying about 'social constructionism' (Papert, 1993), based on the assumption that knowledge is a process of active construction undertaken by individuals and social communities.

In the next paragraphs, thus, we will examine the LI.LO programme and its blended model, which embraces all the assumptions stated earlier, with the aim of building a teaching/learning educational model focused on the development of bilingualism through the use of the computer, the Sybra/CLiRe (Centro Linguistico in Rete) platform and ICT.

\section{The bilingual LI.LO programme}

Beginning with the 2013-2014 academic year, the LI.LO (Italian Language/Heritage Language) programme was started at the Sampierdarena Middle School (Genoa). It was decided that the programme ought to be bilingual, considering that those students whose heritage language was Spanish (even those born and schooled in Italy) achieved lower scores with respect to their Italian native peers on Italian language tests administered to all students. The hypothesis was to work with both languages to balance their bilingualism and improve the CALP.

The goal of the programme, thus, was to develop both Italian and Spanish academic language skills through the use of ICT.

A second aim was to improve study-oriented computer skills, identifying particularly those areas that students were interested in. A blended methodology was adopted with distance learning delivered through a teaching platform and access to appropriate online text books, while traditional classroom teaching took place in a computer laboratory.

The course content tracked the 2012 National Curriculum for Middle Schools (scuola secondaria di primo grado) in geography and history. LI.LO focuses on language as an object of use and not as an object of study, on microlanguage, the use of subject-specific lexis, commitment to a communicative approach, intercultural awareness and the role of ICT. Within the LI.LO project, the same lesson is presented in both Italian and Spanish, thus validating a contrastive approach.

In the next paragraph, the theorethical and methodological approaches of the LI.LO blended model will be shown.

\section{LI.LO programme and blended learning: a balance between virtual and real classrooms}

The selection and integration of technologies into a language course is a complex issue and it depends on many factors (Guichon, 2012). However, several factors influence integration for students and teachers.

The context of this study is the middle school. The first factor taken into consideration is the young age of the pupils and the second is their potential resistance against an e-learning model; these two factors could have caused a strong dispersion.

Because modern teaching methods insist on the figure of the teacher as facilitator of knowledge (Trentin, 2004), this figure, in the blended model, seemed the most suitable to the age of the LI.LO students (11-12 years).

In fact, the blended model 'mixes' the online activities with the face-to-face ones. By using a combination of digital instruction and one-on-one face time, students can work on their own with new concepts, which frees up the teachers sufficiently to circulate and support individual students who may need individualized attention. Furthemore, proponents of blended learning argue that incorporating the 'asynchronous Internet communication technology' into higher education courses serves to 'facilitate a simultaneous independent and collaborative learning experience' (Dreambox 2013). 


\section{Blended learning and bilingual education \\ Firpo}

In LI.LO, the choice of the blended model was successful first because pupils of the middle school need to have in front of them a teacher to guide them towards learning and in selecting content, activities and times of the lesson. This happens especially in the context of lessons in a computer laboratory, where not everyone has the same experience of using the computer and the same cognitive level. Thus, the teacher ought to make sure that all the students start and complete the scheduled activities In order to help the rhythm of the lesson, it is useful to introduce collaborative learning, so that students can help each other, share ideas, speak both languages and build their knowledge together.

Another point of great importance concerns the flexibility of the materials and the teacher's initiative. It is necessary that the teacher has in mind that the time of the lesson can often be slowed due to technical problems (hardware failure or network connection). When this happens, the teachers ought to have flexible material, which means they have to be ready to switch digital materials into books, paper and pencil.

Another fact of slowdown regards the explanation given to students about the computer programmes. In this case, students can cooperate with the teacher and among themselves by exchanging information and competence. Learning a computer programme alone can be very frustrating, but learning the same computer programme with a friend can be very exciting and motivating.

Therefore for all these reasons, the blended learning approach has been considered the one that could better meet the needs of both learners and teachers.

According to Nacamulli (2003), blended learning is expressed in a cyclical process devided into three stages:

1. assisted autonomous learning, based on the usage of online or offline materials;

2. face-to-face training, seen as an opportunity for discussion and collaboration among students who can go into more detail of the topics proposed by the materials in Point 1; and

3. distance activities through an e-learning platform.

In addition to enjoying the online material, students can use tools that encourage active learning.

As regards models of effective learning environments, it seems appropriate to refer to the How People Learn (HPL) model (Bransford, Brown and Cocking, 2000 cit. in Pandolfini 2010, Fig. 5).

Fig. 5. HPL model -How People Learn (Bransford, Brown and Cocking, 2000).

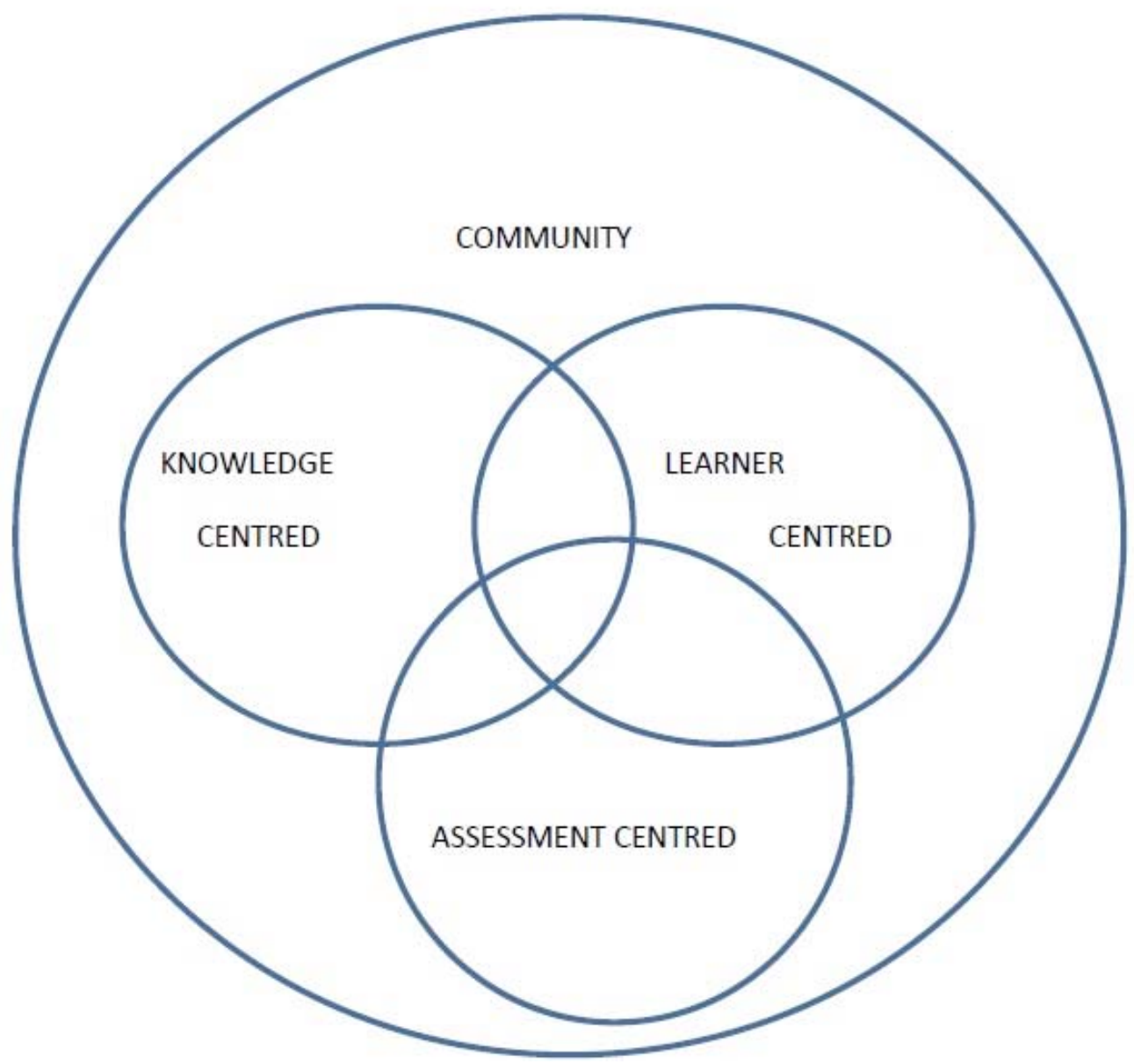

In this model, the learning environments are those centred on knowledge, assessment and community. In the context of this model, Pandolfini (2010) states that: 
- The central role of the student is based on activities that need to be focused on goals, desires and interests of the learners. The best results in terms of learning are achieved when students recognize the usefulness of the knowledge and give a meaning to what they are learning (Bransford, Brown and Cocking, 2000);

- The central role of knowledge is obtained through a blended learning environment that is structured by adopting different teaching strategies, encouraging students to 'do' the work, fostering a better understanding rather than memorization of notions of discipline and promoting thus the development of new skills (Shea, 2007);

- The focus of the evaluation is implemented by helping students to make visible their thoughts, providing constant feedback and revisions, which are given not only by the teachers and tutors but also by other students involved in the learning process;

- The comparison between peers is the key to meeting the central role of the community, within which lie the other aspects.

All these elements are found in the blended LI.LO model and can be represented as in Fig. 6.

Fig. 6. LI.LO blended model.

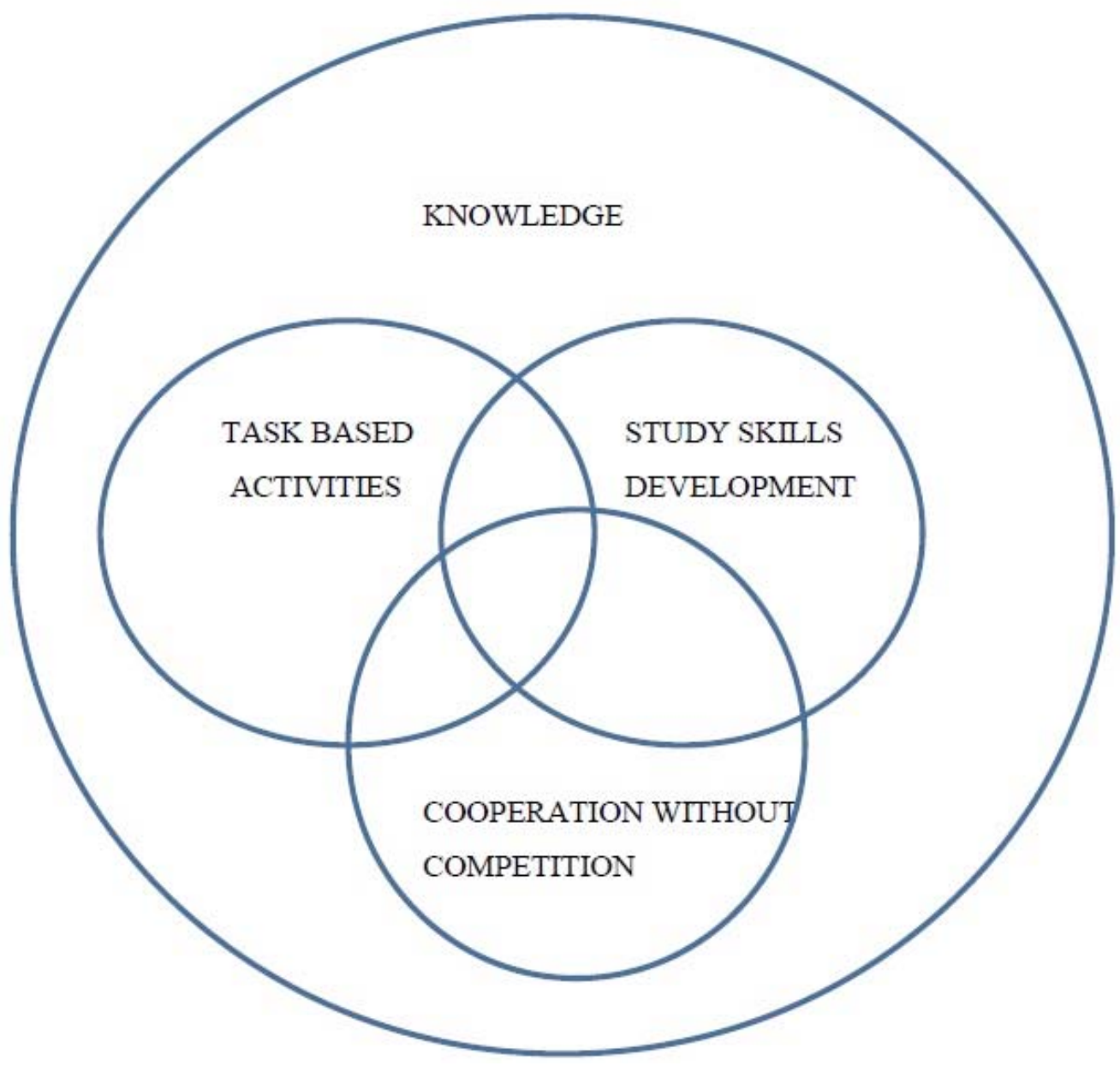

Figure 6 shows the LI.LO blended model in which:

- Knowledge is based on task-based activities that need to be focused on the task-based activities prepared by the teacher. They are based on the analysis of needs and ought to respect the needs of learners and their interests.

- Knowledge is achieved through the adoption of different teaching strategies encouraging students to 'do' the work, fostering a better understanding rather than memorization of notions of discipline and promoting thus the development of new skills (Shea, 2007);

- Knowledge comes through cooperation between the sudents, the exchange of ideas and mutual help in carrying out tasks. The teacher should encourage a cooperative attitude and discourage competition between individuals and between groups; the learning process not only becomes a technical type of teaching, but it is also built through inclusion and sharing processes.

In conclusion, it is possible to say that the methodological aspects of LI.LO are varied, and it is not possible to categorize them into one model. They indeed take into account purely linguistic models (such as the Lexical Approach, Lewis 1993) together with other methodological aspects (CLIL, Coonan 2014); the whole learning process is assisted by the operation of models, such as the blended model of LI.LO illustrated in Fig. 6. 
In the next two paragraphs, we illustrate the activities of the course and the discussion of the data, particularly the evaluation and self-assessment questionnaires of the Spanish-speaking student group that participated in the LI.LO Programme.

\section{Course activities}

The activities of the course focused on three main areas: 1) comprehension skills, 2) expansion and development of the discipline vocabulary and 3) use of language (written production). The materials provide listening and comprehension exercises through audio or video (with exercises of true/false choice, cloze test, match, etc.) and via reading of authentic texts and identification of keywords through specific exercises for vocabulary development (matching word/image or word/meaning, semantic and lexical extension classification through the use of concept maps, etc. $)^{4}$.

For the written production section, the students started their literacy in Spanish through a comparative analysis of the handwriting of the two languages, Italian and Spanish, in order to highlight the potentially critical points. In addition, the researchers created and administered initial exercises of recognition of phonemes and graphemes through listening activities, identification and selection of graphemes, as well as dictation tasks -first in Spanish, second in Italian and then alternately in both languages.

As for the lexical area, they selected words related to the subjects geography and history. In the second step, to bring the students to the level of written production of a short text, the researchers chose a cartoon programme (GoAnimate) which, through images, sounds, texts and comics, has the elaboration of the learnt content, from both phonological and lexical points of view, as its objective. These activities make the writing process very motivating for the students, despite the fact that initial screening showed strong critical issues in this area (Firpo 2014). Later on, the students uploaded their cartoons on Facebook LI.LO group also, in order to share them in the social networks.

The activities carried out with the support of technologies, especially those in which students developed content, achieved big success among students. The collected data on networked interactions show that students participated actively in the activities.

\section{Methodology}

The LI.LO project is divided into two phases: in phase one, before defining the course objectives, data had to be collected on the basis of the linguistic and communicative abilities put into use at school by students of non-Italian origin. These students typically cannot be classed as immigrants who have recently arrived in Italy. Two tools were used: a language test and linguistic biography. The tests were given to all fifth-year, primary school students at I.C. Sampierdarena in Genoa during June 2013. The qualitative and quantitative analyses in phase one enabled us to design the LI.LO course according to the learners' needs (Firpo and Sanfelici 2015).

In phases two and three (the first and the second editions of the course), the quantitative and qualitative analyses were repeated at the beginning and the end of the course. The LI.LO language test was used both to assess students' entry knowledge as well as to monitor the progress of those who had taken part in the first edition of LI.LO, comparing the sample of the Hispanophone students who had followed the course with the sample of Italian students. Linguistic biographical data helped to provide a picture of learners' school and language history, as well as the sociolinguistic background. ${ }^{5}$ The language tests were taken by all first-year, middle school students at I.C. Sampierdarena at the beginning of the course (February 2014) and at the end (May 2014). In this article, we will not focus on the statistical analysis of the data generated by the LI.LO language test (Firpo and Sanfelici 2015), but it might be useful to introduce very briefly the results of the linguistic tests in the two phases.

In the first phase, the data collected helped to establish the level of the students both personally and linguistically in order to define the objectives and modality of a bilingual course. Fifty-six students participated in the research (20 Italian and 30 Hispanophone) and they were nearly 10 years old.

\section{Findings and discussion}

As regards language, the mean scores of the linguistic test recorded by Italian students were higher than those achieved by Hispanophones. However, for Hispanophone students, the scores were the highest in Italian as a language of study. In fact, in the correlation between the scores in the two languages, tests in Italian had higher mean scores than those in Spanish. This result supports the hypothesis that the students under examination are not balanced bilinguals, but that they use their language of origin only in family circles and do not possess academic proficiency in it.

\footnotetext{
${ }^{4}$ Some of the ICT tools used for LI.LO are YouTube, Audacity, Hot Potatoes, CMap, GoAnimate, Word, PowerPoint, Google Maps and online dictionaries.

${ }^{5}$ Further discussion of the qualitative analysis of the linguistic biography, course objectives and the use of teaching technologies can be found in Firpo and Torsani (2014), Firpo (2014) and Firpo and Sanfelici (2014).
} 


\section{Blended learning and bilingual education \\ Firpo}

Furthermore, in phase one, a questionnaire (linguistic biography) was used to collect information about the computer competences and interests of the students. The questionnaire consisted of two parts:

1. General school background and languages spoken

2. Interests and competence in ICT and Web 2.0 tools.

In this article, we provide a view of the general results of the second part of the questionnaire. As seen in Table 1, almost all of the students have a computer, but only half have a mobile device. Most of them use technologies to play, chat and download. Students of this school seem very far from using the Web 2.0 and the ICT for study purposes.

\begin{tabular}{|c|c|c|c|}
\hline \multirow[t]{2}{*}{ Do you use the computer at school? } & Yes & Sometimes & No \\
\hline & $15 \%$ & $81 \%$ & $4 \%$ \\
\hline \multirow[t]{3}{*}{ Have you got... } & A computer & A mobile device & Internet \\
\hline & Yes & Yes & Yes \\
\hline & $98 \%$ & $48 \%$ & $98 \%$ \\
\hline \multirow[t]{2}{*}{ What do you do with the computer? (we give only the main three answers) } & Play videogames & Download music & Watch videos \\
\hline & $47 \%$ & $16 \%$ & $9 \%$ \\
\hline \multirow[t]{2}{*}{ What do you do with the mobile device? (we give only the main three answers) } & Play videogames & Download & Chat \\
\hline & $37 \%$ & $23 \%$ & $24 \%$ \\
\hline
\end{tabular}

Table 1. Questionnaire of phase one: needs analysis.

In conclusion, the analysis of learners' needs in the first part showed, on the one hand that the Hispanophone students are not balanced bilinguals. On the other hand, they do not use technologies to study. On the basis of this, LI.LO was designed as a bilingual course with teaching materials both in Spanish and Italian. The course objective was to develop the language of study through the exploitation of lexis with the aid of ICT.

In the second and the third phases (scool years 2013/2014 and 2014/2015), the LI.LO course was conducted. In both phases, a language test was used to perform both an initial and a final screening of all first year, middle school students attending I.C. Sampierdarena. Three groups were examined: the sample of Italian students (39 students); the sample of Hispanophone students who followed the LI.LO course (totally 30 students); the sample of Hispanophone students who did not follow the LI.LO course (totally 44 students). The results that emerged in the analysis of the linguistic test (time 1 vs. time 2) showed that the LI.LO course helped develop the language of study through heightened ability for comprehension in both languages and in use of the language, particularly in Italian.

In addition to the analysis of the effectiveness of the course (Firpo 2014; Firpo and Sanfelici 2015), as part of the LI.LO project, attendees were given a post-course assessment and a self-assessment ${ }^{6}$ questionnaire covering the following areas:

1. Teaching

2. Equipment and resources

3. Students' perception of their linguistic identity

The methodological approach adopted can be called exploratory and non-qualitative as the methods of collection (investigation) and analysis (descriptive statistics) are fundamentally quantitative (Arthur, Waring, Coe \& Hedges 2012; Tashakkori \& Teddlie 2014).

The questionnaire has five sections:

1. Quality of the work done

2. Quality of the tools and arguments

3. Self-assessment of the course

4. ICT

5. Global evaluation.

For the post-course questionnaire, there were 25 respondents.

${ }^{6}$ The questionnaire was constructed using Google Drive:

https://docs.google.com/forms/d/1qxsR5_04VvphjmXRUXt917c4_cBTBkzTu0rX1ys53Y8/viewform 
The five parts of the questionnaire included 39 items used to measure the quality of the activities undertaken during the course and the type of ICT/Web 2.0 used in the classroom as a way to promote metalinguistic awareness. Furthemore, parts 3 and 5 asked the students to reflect on their learning process by answering questions about improvement of competences that included both linguistic and study skills. Despite 30 students attending LI.LO, only 25 answered the questionnaire because participation was voluntary.

Most of the questions attributed a score measuring the levels of satisfaction from a minimum of one to a maximum of five. For instance, in the section dedicated to the quality of the work (Table 2), on average, $76 \%$ of students gave a rating from four to five regarding satisfaction with personal progress made, $80 \%$ of students on the usefulness of the activities carried out and $76 \%$ of them regarding the quality of classroom management by teachers.

\begin{tabular}{llllll} 
QUALITY OF THE WORK DONE & 1 & 2 & 3 & 4 & 5 \\
\hline & 1 & 1 & \\
\hline The course taken has met your personal expectations? & $0(0 \%)$ & $2(8 \%)$ & $4(16 \%)$ & $11(44 \%)$ & $8(32 \%)$ \\
\hline Do you think activities were useful? & $0(0 \%)$ & $2(8 \%)$ & $3(12 \%)$ & $15(60 \%)$ & $5(20 \%)$ \\
\hline The quality of classroom management by teacher was: & $0(0 \%)$ & $0(0 \%)$ & $6(24 \%)$ & $10(40 \%)$ & $9(36 \%)$
\end{tabular}

Table 2. Quality of the work done.

As for the quality of equipment and subject areas studied (Table 3), scores between four and five were given for the following topics, with percentage of respondents in brackets: instruments/equipment used $(80 \%)$; subjects $(80 \%)$; support materials $(68 \%)$; and satisfaction with platform $(82 \%)$.

QUALITY OF THE EQUIPMENT AND SUBJECT AREAS STUDIED
\begin{tabular}{llllll}
\hline \\
\hline The quality of the technological tools used was: & 1 & 2 & 3 & 4 & 5 \\
\hline The quality of the subjects and the topics treated was: & $0(0 \%)$ & $0(0 \%)$ & $5(20 \%)$ & $14(56 \%)$ & $6(24 \%)$ \\
\hline The quality of the support materials (texts) was: & $0(0 \%)$ & $1(0 \%)$ & $7(32 \%)$ & $13(36 \%)$ & $4(32 \%)$ \\
\hline The platform CLiRe was: & $0(0 \%)$ & $1(4 \%)$ & $7(28 \%)$ & $13(52 \%)$ & $4(16 \%)$ \\
\hline Did you enjoy studying with the platform CLiRe? & $0(0 \%)$ & $1(4 \%)$ & $4(16 \%)$ & $9(36 \%)$ & $11(44 \%)$
\end{tabular}

Table 3. Quality of the equipment and the subject area studied.

Turning to ITC activities (Table 4), those considered the mostly liked (64\%) and the easiest (80\%) related to the use of video to present an overview of each learning module, while the most difficult was text reconstruction used as a vehicle for synthesis and summarizing, as well as mind mapping. Nevertheless, linguistic exercises made with the platform and the tools were considered the most useful: word dictation, text reconstruction (wich was also difficult), cloze and matching exercises.

\begin{tabular}{lllll} 
TOOLS & mostly liked & easiest & most difficult & most useful \\
\hline Text writing (Word) & $32 \%$ & $32 \%$ & $28 \%$ & $44 \%$ \\
\hline Instructional videos (YouTube) & $64 \%$ & $80 \%$ & $4 \%$ & $40 \%$ \\
\hline Presentation and Slideshows (Powerpoint) & $20 \%$ & $24 \%$ & $4 \%$ & $28 \%$ \\
\hline Mind Mapping (CMap) & $40 \%$ & $16 \%$ & $52 \%$ & $48 \%$ \\
\hline Matching exercises word/picture & $48 \%$ & $40 \%$ & $8 \%$ & $48 \%$ \\
\hline Cloze & $28 \%$ & $20 \%$ & $20 \%$ & $60 \%$ \\
\hline Text reconstruction & $24 \%$ & $24 \%$ & $52 \%$ & $64 \%$ \\
\hline Matching exercise word/meaning & $44 \%$ & $32 \%$ & $8 \%$ & $56 \%$ \\
\hline Cartoon (GoAnimate) & $44 \%$ & $40 \%$ & $16 \%$ & $24 \%$ \\
\hline Word dictation & $40 \%$ & $48 \%$ & $24 \%$ & $76 \%$
\end{tabular}

Table 4. Tools.

Scores between four and five were also recorded in the evaluation of the progress made regarding the use of ICT (Table 5), which seems to be changed after the course (72\%). Students learnt the use of new tools $(82 \%)$, which they considered very helpful. 


\begin{tabular}{llllll} 
& 1 & 2 & 3 & 4 & 5 \\
\hline Was LI.LO helpful to learn new tools? & $0(0 \%)$ & $0(0 \%)$ & $5(20 \%)$ & $11(44 \%)$ & $9(36 \%)$ \\
\hline Do you think you have learned a new way to use the Internet? & $0(0 \%)$ & $1(4 \%)$ & $5(20 \%)$ & $9(36 \%)$ & $10(40 \%)$ \\
\hline After LI.LO, did you change your way of using the Internet? & $2(8 \%)$ & $1(4 \%)$ & $4(16 \%)$ & $14(56 \%)$ & $4(16 \%)$ \\
\hline Did you enjoy LI.LO's Facebook Group? & $2(8 \%)$ & $1(4 \%)$ & $5(20 \%)$ & $7(30 \%)$ & $9(38 \%)$ \\
\hline Paticipating in LI.LO has been a good opportunity for you? & $0(0 \%)$ & $1(4 \%)$ & $4(16 \%)$ & $13(52 \%)$ & $7(28 \%)$ \\
\hline Using ICT for studying is helpful & $0(0 \%)$ & $0(0 \%)$ & $1(4 \%)$ & &
\end{tabular}

Table 5. ICT

The general assessment of the course ( $85 \%$ of responses assigned a score between four and five) was positive. The areas of study in order of satisfaction level are use of language (58\%); knowledge of lexis (26\%) and comprehension $(16 \%)$.

Scores between four and five were also recorded in the self-assessment questionnaire. They are as follows: $79 \%$ believed that the course helped to improve self-esteem; $64 \%$ thought that the course had raised interest in the subject; and $53 \%$ felt that they had improved their self-study skills and knowledge of the subject in general. Self-assessment of language-related progress revealed a perceived improvement in use of the language (42\%), knowledge of lexis (32\%) and in comprehension (26).

Finally, on the question of the response by families to the questionnaire, only $23 \%$ of student families completed and returned the form. This would appear to suggest that these students' families take little part in their children's school life, a fact that is confirmed by teachers, who point out the lack of parental participation. However, those who did complete the questionnaire expressed their satisfaction with the LI.LO project, along with the hope that the language of origin be maintained.

\section{Conclusions}

LI.LO. can be considered an instructional-educational model that aims to strengthen the channels of communication and collaboration between school and territory. On the one hand, the programme aims to build a more open school community. On the other hand, it aims to open a more sensitive social context to the educational urgencies.

As regards language, the results that emerged in the final analysis of data showed that the LI.LO course helped develop the language of study through heightened ability for comprehension in both languages and in use of the language, particularly in Italian (Firpo and Sanfelici 2015).

As regards computer use, however, it is possible to observe how the use of technologies for the construction of multimedia products has revealed a successful choice. The participation of the students was very active and this can be considered one of the most important elements for linguistic appropriation. The task of transformation, which is a typical activity that develops the CALP, has been made more motivating from the use of computer programmes for the production of content.

In fact, ICT and Web 2.0 tools provide a variety of different approaches as well as learning styles that might reinforce the material delivered in other formats. In addition, enjoyment and motivation are very much a part of effective learning (Stevick, 1990).

Shezer snd Warschauer (2000) state that the Web can support both computer-mediated communication tools and language teachers in integrating Web resources into the language classroom. Furthermore, ICT can captivate learners' interest, increase personal discovery, as well as generate enthusiasm and the desire to learn (McDougald, 2009). The Web offers a very big amount of authentic materials for language learning (texts, videos, images, sound reconding, etc.), allowing the teachers and the learners to cross borders without even leaving their country. During geography lessons, e.g. LI.LO's students could virtually travel to their countries of origin simply by using Google Maps or Google Earth. They had found their relatives' homes and this, for instance, was an excellent motivation to search for more information and to share findings and ideas with the community.

The final data, therefore, allow following two future research paths. The first one is related to cognition, and it concerns the activities used for the development of CALP. The second, more interesting from the point of view of language learning, involves the validity of the paradigm that sees the use of technologies for the production of content as a motivating tool, even in the long term.

In conclusion, the use of ICT has changed our conventional way of learning and proposes the need to rethink education in terms of a more current context. According to the previous statement, LI.LO aims to be an experimental research-activity addressed to minority languages and, generally, disadvantaged students.

On the basis of our findings, it is hoped that foreign language teaching moves towards the development of linguisticcommunicative abilities in the language of study and a more balanced bilingualism both for non-Italophone students and, in the future, for all students in Italian schools, with the objective of creating schools -and the citizens they produce -that embrace plurilingualism and interculturalism. 


\section{References}

Arthur, J., Waring, M., \& Coe R.,and Hedges L.V. (2012). Research Methods and Methodologies in Education. London: Sage Pubns Ltd.

Bransford, D., Brown, A. \& Cocking, R. (2000). How people learn: brain, mind, experience and school. Washington D.C: National Academic Press.

Bonaiuti, G. \& Calvani, A. (2007). Fondamenti di Didattica. Teoria e Prassi dei dispositivi formativi. Roma: Carocci.

Coonan, C. M. (2014). I principi base del CLIL. In Paolo Balboni (Ed.). Fare CLIL. I quaderni della ricerca 14, 17-35. Torino: Loescher Editore.

Cummins, J.(1979b). Cognitive/academic language proficiency, linguistic interdependence, the optimum age question and some other matters. Working Papers on Bilingualism, 19,121-129.

Cummins, J. (2002). Lenguaje, poder y pedagogía. Madrid: Ediciones Morata, S.L.

Dreambox (2013). Five benefits of blended learning. Retrieved from http://www.dreambox.com/blog/five-benefits-ofblended-learning

Dudley-Evans, T. \& St John, M. (1998). Development in English for Specific Purposes. A multi-disciplinary approach. Cambridge: Cambridge University Press.

Firpo, E. (2014). "Una proposta di adattamento al test Italstudio" in EL.LE, Vol. 3, N. 3 Novembre 2014, Digital Publishing, Edizioni Ca' Foscari, ISSN 2280-6792 retrieved from http://virgo.unive.it/ecfworkflow/upload_pdf/ELLE_3_3_2014_003_Firpo.pdf

Firpo, E. (2014). L'italiano per lo studio e la lingua d'origine. LI.LO: un progetto bilingue per la scuola secondaria di primo grado.Lingu@ggi 21.0, n. 2, 2014, retrieved from http://www.linguaggi21punto0.unige.it/blog/numero-ii$\underline{2014 /}$

Firpo, E. \& Sanfelici, L. (2015). De ELE al desarrollo de la CALP y de la metacompetencia bilingüe. Educatio siglo XXI, 33 (1), retrieved from http://revistas.um.es/educatio/article/view/222611.

Giscel (Ed.). (2007). Educazione linguistica democratica. A trent'anni dalle Dieci Tesi. Milano: Franco Angeli.

Gruba, P. (2004). Computer assisted Language Learning (CALL). In Davies, A. \& Elder, C. (Eds), The Handbook of Applied Linguistics, 623-648. London: Blackwell Publishing Ltd.

Lea, M. \& Street, B. (2000). Staff feedback: an academic literacies approach. In M. Lea \& B. Stierer (Eds.). Student Writing in Higher Education: New Contexts. Open University Press.

Mezzadri M. (2011). Studiare in Italiano. Certificare l'italiano L2 per fini di studio. Milano: Mondadori Università.

Lewis, M. (1993). The Lexical Approach. Hove: Language Teaching Publications.

Ligorio, M. B. (1995). Le Community of Learners. In A. Calvani and B. M. Varisco (Eds), Costruire/decostruire significati. Ipertesti, micromondi e orizzonti formativi, 197-219. Padova: Cleup.

Mason, L. (2006). Psicologia dell'apprendimento e dell'istruzione. Bologna: Il Mulino.

McDougald, J. S: (2009). The state of language and content instruction in Columbia. Retrieved from http://revistas.unisabana.edu.co/index.php/LACLIL/article/viewFile/2606/2742. doi:10.5294/laclil.2009.2.2.15

MIUR (Ministero della Istruzione, dell'Università e della Ricerca), Servizio Statistico. (Ottobre 2015). Gli alunni $\begin{array}{lllll}\text { stranieri nel sistema } & \text { scolastico } & \text { 2014/2015. } & \text { Retrieved from }\end{array}$ http://www.istruzione.it/allegati/2015/Notiziario Alunni Stranieri 1415.pdf ultima consultazione 22 gennaio 2016.

Nacamulli, R.D. (Ed). (2003). La formazione, il cemento e la rete. Milano: Etas.

Pallotti, G.(1998). La seconda lingua. Milano: Strumenti Bompiani.

Pandolfini, V. (2010). Dal gessetto alla tastiera, Formazione e comunità on line tra classi reali e virtuali. Milano: Ledizioni.

Papert, S. (1993). The Children's Machine: Rethinking School in the Age of the Computer. New York: Basic Books.

Peacock, J. \& Flowerdew, M. (2001). Issues in EAP. A preliminary perspective. In J. Peacock \& M. Flowerdew (Eds.) Research Perspectives on English for Academic Purposes. Cambridge and New York: Cambridge University Press.

Rumbaut, R. G. (1997). Ties that bind: Immigration and Immigrant Families in the United States. In A. Booth, Crouter, A.C. \& N. Landale (Eds.), Immigration and the Family. Mahawah, New Jersey: Lawrence Elrbaum Associated Publishers.

Shea, P. (2007). Towards a conceptual framework for learning in blended environments. In A. G. Picciano \& C. D. Dziuban (Eds.), Blended Learning: research perspectives (pp. 19-35), Needham, MA: Sloan C.

Shetzer, H. \& Warschauer, M. (2000). An electronic literacy approach to network-based language teaching. In M. Warschauer \& R. Kern (Eds.), Network-based language teaching: Concepts and practice, 171-185. New York: Cambridge University Press.

Stevick, E. W. (1990). Humanism in language teaching. Oxford: Oxford University Press.

Suppes, P. \& Maken, E. (1978). The Historical Path From Research and Development to Operational Use of CAI. In Educational Technology 18, 9.12.

Teddlie, C. \& Tashakkori, A. (2011). Mixed methods: Contemporary issues in an emerging field. In N. K. Denzin \& Y. S. Lincoln (Eds.), Handbook of qualitative research (4th ed.). Thousand Oaks, CA: Sage.

Trentin, G. (2004). Apprendimento in rete e condivisione delle conoscenze: ruolo, dinamiche e tecnologie delle comunità professionali online (Vol. 6). Milano: FrancoAngeli. 
Warschauer, M. \& Kern, R. (2000). Theory and Practice of Network-based Language Teaching. In Warschauer M. \& Kern R. (Eds) Network-based Language Teaching. 1-19. Cambridge: Cambridge University Press.

Warschauer, M. (1996). Computer Assisted Language Learning: An Introduction. In S. Fotos (Eds). Multimedia Language Teaching, 3-20. Tokyo: Logos International. 